\title{
Kajian Fisis pada Gerak Osilasi Harmonis
}

\author{
Esmar Budi \\ Program Studi Pendidikan Fisika, Fakultas Matematika dan Ilmu Pengetahuan Alam \\ Universitas Negeri Jakarta, Jl. Pemuda No. 10 Rawamangun Jakarta 13220 Indonesia \\ E-mail: esmarbudi@unj.ac.id
}

\begin{abstract}
This article explain the study on a simple harmonic oscillation. The study was conducted through laboratory experiments on simple oscillatory motion on the system as well as the physical pendulum spring-mass system, using experimental tools JEULIN device equipped with a Generis +5 software. Results of this experiments on oscillatory motion of a physical pendulum system shows that the simple harmonic oscillation is met if the initial deflection system is small $(<100)$. As for the spring-mass system, simple harmonic oscillation properties are determined by the value of the spring constant of the system and the mass of the system load. The amplitude oscillatory motion increases with increasing system load.
\end{abstract}

Keywords: simple oscillatory motion, angle of deviation, the system physical pendulum, spring-mass system, amplitude, period.

\begin{abstract}
Abstrak
Artikel ini memuat kajian pada osilasi harmonis sederhana. Kajian dilakukan melalui kegiatan percobaan di laboratorium pada gerak osilasi sederhana pada sistem bandul fisis serta sistem pegas-massa, menggunakan perangkat alat percobaan Jeulin berbantuan komputer yang dilengkapi dengan perangkat lunak Generis +5 . Hasil percobaan pada gerak osilasi sistem bandul fisis menunjukan bahwa osilasi harmonis sederhana terpenuhi jika simpangan awal sistem adalah kecil $(<100)$. Sedangkan untuk sistem pegas-massa, sifat osilasi harmonis sederhana ditentukan oleh nilai tetapan pegas sistem dan massa beban sistem. Amplitudo gerak osilasi meningkat seiring dengan peningkatan beban sistem.
\end{abstract}

Kata-kata kunci: gerak osilasi sederhana, sudut simpangan, sistem bandul fisis, sistem pegasmassa, amplitudo, perioda.

\section{PENDAHULUAN}

Gerak osilasi merupakan gerak periodik suatu benda atau sistem mekanik melalui suatu titik kesetimbangan. Sistem mekanik dapat bergerak secara periodik yang diakibatkan oleh bekerjanya gaya pemulih pada sistem tersebut (Serway 2014). Gaya pemulih yang bekerja adalah sebanding terhadap kedudukan relatif massa sistem terhadap titik kesetimbangan dan selalu berarah menuju titik kesetimbangan tersebut. Gerak ini disebut sebagai gerak osilasi harmonis sederhana. Secara umum sistem mekanik dapat digambarkan oleh sistem bandul matematis dan sistem pegas-massa seperti yang ditunjukan GAMBAR 1 dan GAMBAR 2: 


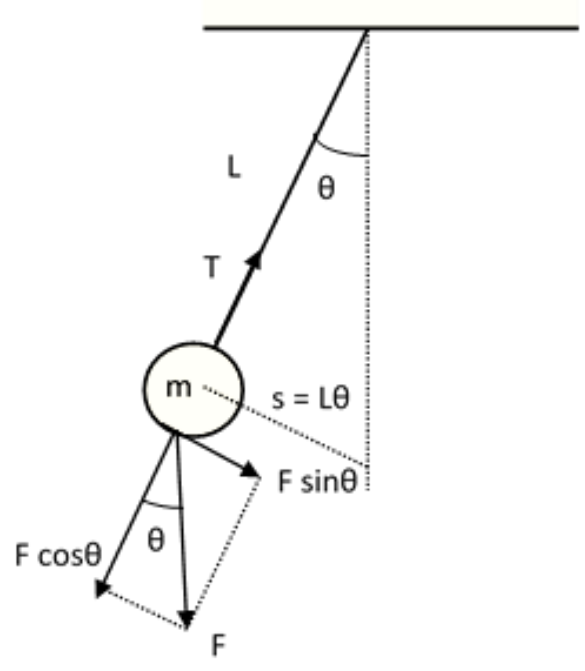

GAMBAR 1. Osilasi harmonis sederhana sistem bandul matematis.

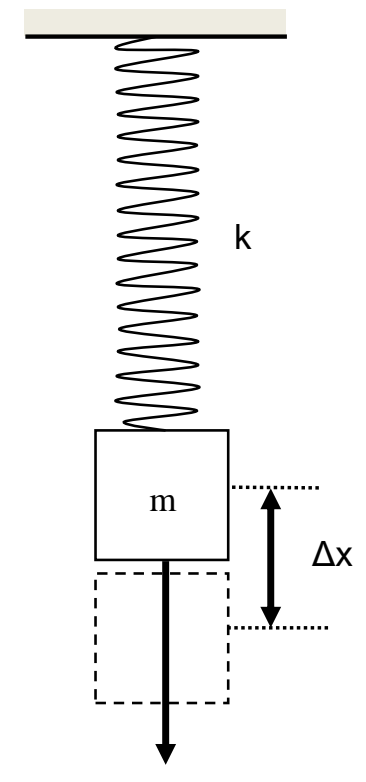

$\mathrm{X}$

GAMBAR 2. Osilasi harmonis sederhana sistem pegas-massa.

Secara umum gerak osilasi sederhana sistem bandul matematis dinyatakan dengan rumusan sebagai berikut (Jeulin - Study of simple pendulum):

$$
\begin{aligned}
& \frac{d^{2} \theta}{d t^{2}}+\omega^{2} \theta=0 \\
& \omega^{2}=\frac{g}{L} \\
& T=2 \pi \sqrt{\frac{L}{g}}
\end{aligned}
$$

dengan $\omega=$ frekuensi sudut osilasi, $T=$ perioda osilasi, $g=$ percepatan gravitasi, $\operatorname{dan} L=$ panjang tali bandul.

Untuk sistem pegas-massa persamaan umum gerak osilasi harmonis sederhana dapat ditulis (Jeulin - Oscillation of an elastic along a vertical axis): 


$$
\begin{aligned}
& \frac{d^{2} x}{d t^{2}}+\omega^{2} x=0 \\
& \omega^{2}=\frac{k}{m} \\
& T=2 \pi \sqrt{\frac{m}{k}}
\end{aligned}
$$

dengan $k=$ tetapan pegas dan $m=$ massa sistem.

Untuk sistem bandul fisis seperti GAMBAR 3, karena kedudukan pusat massa sistem bandul matematis berbeda dengan kedudukan pusat massa pada fisis maka dapat ditulis:

$$
\begin{aligned}
& T=2 \pi \sqrt{\frac{m}{k}} \\
& \omega^{2}=\frac{m g L}{2 I} \\
& T=2 \pi \sqrt{\frac{2 I}{m g L}}
\end{aligned}
$$

dengan $I=$ momen lembam batang bandul.

Jika $I=m(L / 2)^{2}$, maka persamaan umum gerak osilasi bandul fisika adalah sama dengan persamaan umum gerak osilasi sederhana bandul matematis (PERSAMAAN 1).

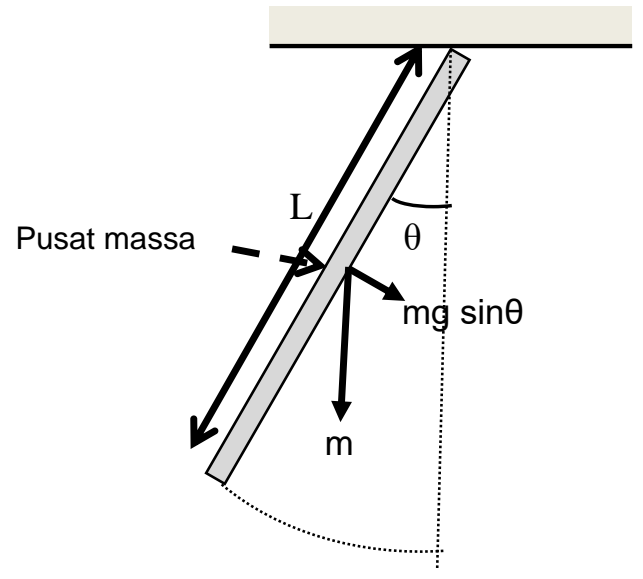

GAMBAR 3. Osilasi harmonis sistem bandul fisis.

Kajian ini mempelajari gerak osilasi harmonis sederhana khususnya mengkaji perubahan periode, frekuensi dan amplitudo osilasi terhadap perubahan/ variasi simpangan atau sudut awal pada gerak bandul fisis dan variasi massa beban pada gerak osilasi sistem.

\section{PERCOBAAN}

Percobaan gerak osilasi sederhana dilakukan menggunakan perangkat alat Jeulin untuk sistem pegas-massa dan bandul fisis berbantuan komputer dilengkapi dengan perangkat lunak Generis +5 . Perangkat dilengkapi alat pengubah analog ke digital VVT (Science Studio software package \& Budi 2013).

\section{Osilasi bandul fisis}

Sebuah sensor sudut digunakan untuk mendeteksi sudut simpangan gerak osilasi batang bandul fisis dengan variasi sudut simpangan awal yang dilakukan pada percobaan ini adalah sebesar $5^{\circ}, 10^{\circ}$, $15^{\circ}, 20^{\circ}, 25^{\circ}, 30^{\circ}$ dan $35^{\circ}$ (W. Ferra Prawati 2013). Analisis dilakukan untuk mengkaji pengaruh 
perubahan sudut simpangan awal terhadap amplitudo dan perioda osilasi untuk waktu osilasi selama 10 detik.

\section{Osilasi pegas-massa}

Sebuah sensor gaya digunakan untuk mendeteksi perubahan gaya terhadap periode waktu osilasi. Variasi massa beban sistem yang dilakukan pada percobaan ini adalah 5-30 gram. Dua buah pegas berjenis bahan sama namun berbeda ukuran digunakan dalam percobaan ini (pegas\#1: $l=10 \mathrm{~cm}$, $\phi=0.8 \mathrm{~cm}, k=7561 \mathrm{~N} / \mathrm{m}$, pegas $\# 2: l=10 \mathrm{~cm}, \quad \phi=0.8 \mathrm{~cm}, k=4432 \mathrm{~N} / \mathrm{m}$ ) (Budi 2013). Analisis dilakukan untuk mengkaji perubahan amplitudo dan perioda osilasi terhadap perubahan massa beban sistem. Untuk sistem pegas-massa dengan orientasi vertikal, berat beban akan memberikan pertambahan panjang pada pegas. Karena itu keadaan awal sistem adalah ditetapkan saat beban tergantung pada pegas.

\section{HASIL DAN PEMBAHASAN}

\section{Osilasi harmonis sistem bandul fisis}

Hasil perobaan pada osilasi sistem bandul fisis dengan variasi sudut awal perpindahan $5^{\circ}, 10^{\circ}, 15^{\circ}$, $20^{\circ}, 25^{\circ}, 30^{\circ}$ dan $35^{\circ}$ ditunjukan pada GAMBAR 4 dengan hasil percobaan ditunjukan oleh kurva titik-titik sedangkan hasil perhitungan model ditunjukan oleh kurva garis kontinyu. Hasil percobaan yang dibandingkan dengan hasil simulasi menunjukkan bahwa, untuk sudut awal simpangan $5^{\circ}, 10^{\circ}$, dan $15^{\circ}$, secara umum kesesuaian hanya ditunjukan oleh sudut awal $5^{\circ}$ dan $10^{\circ}$ (GAMBAR 5). Untuk sudut simpangan awal $15^{\circ}$ ketidaksesuaian antara hasil percobaan dengan simulasi mulai terlihat. Sementara itu sudut simpangan awal yang lebih besar seperti $20^{\circ}, 25^{\circ}, 30^{\circ}$ dan $35^{\circ}$, ketidaksesuaian antara hasil percobaan dengan simulasi semakin terlihat (GAMBAR 6).

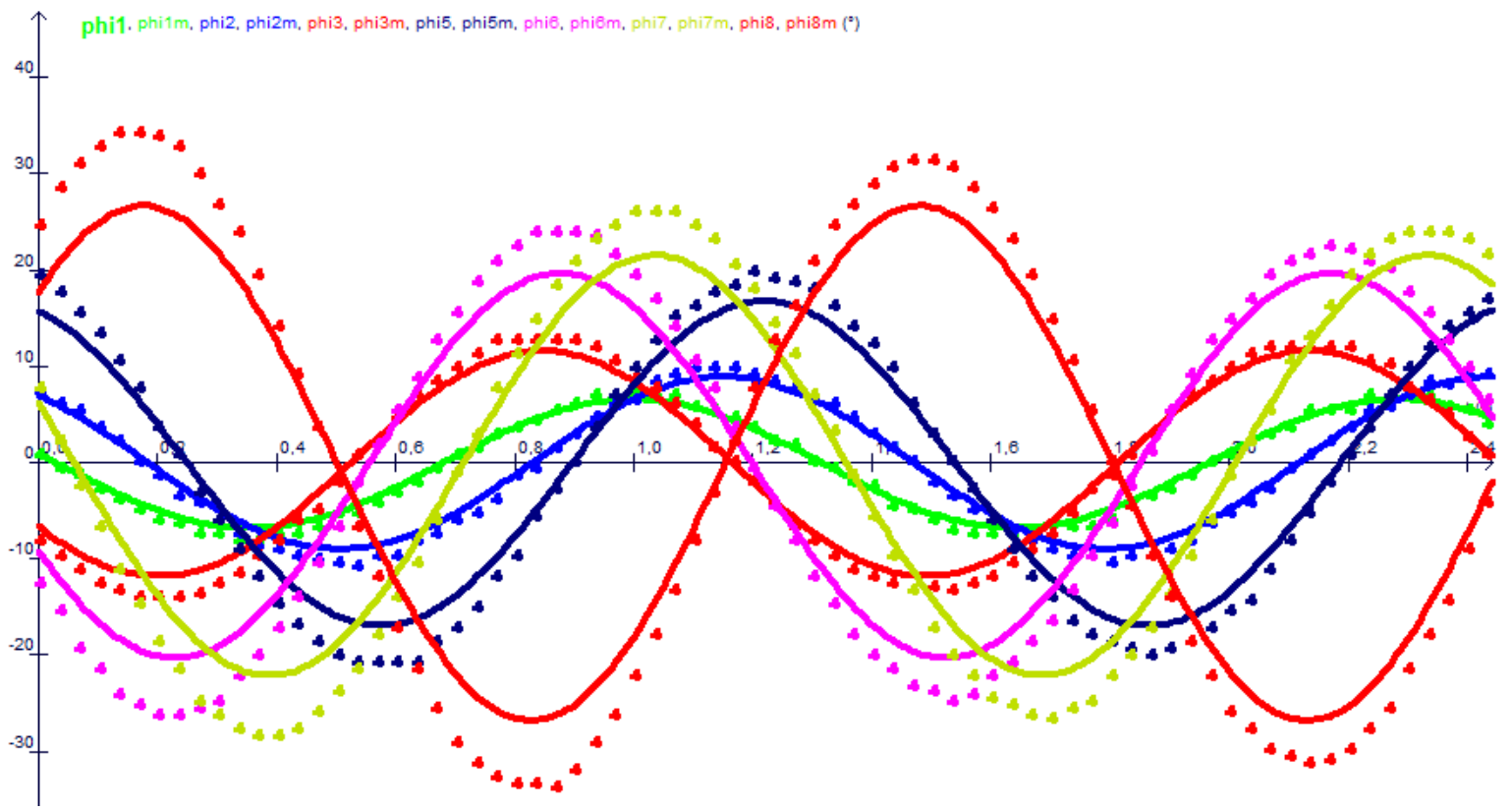

GAMBAR 4. Kurva gerak osilasi harmonis sederhana sistem bandul fisis dengan variasi sudut awal perpindahan $5^{\circ}, 10^{\circ}$, $15^{0}, 20^{\circ}, 25^{\circ}, 30^{\circ}$ dan $35^{\circ}$. Hasil percobaan ditunjukan oleh kurva garis titik-titik sedangkan hasil simulasi ditunjukan oleh kurva garis kontinu. 


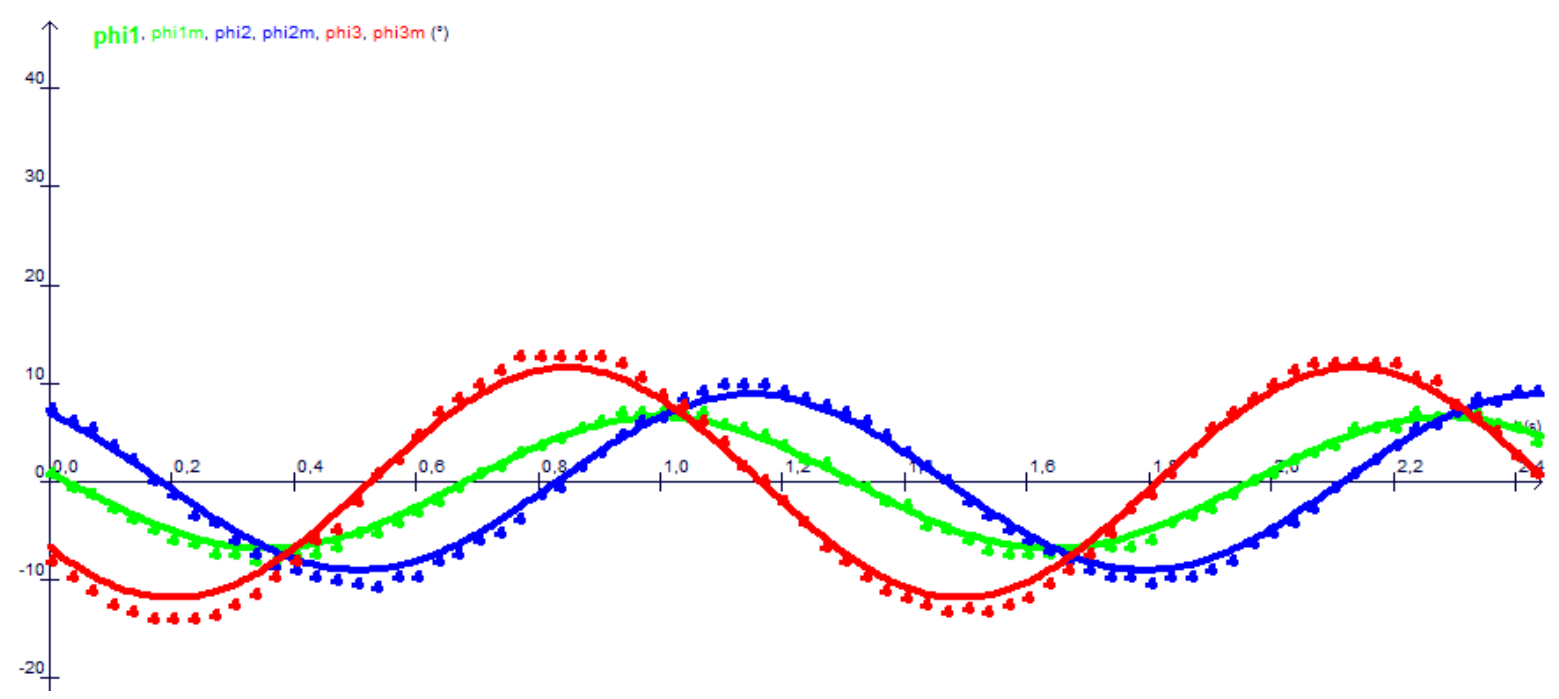

GAMBAR 5. Kurva gerak osilasi harmonis sederhana sistem bandul fisis dengan variasi sudut awal perpindahan $\left(5^{\circ}, 10^{\circ}\right.$, dan $15^{\circ}$ ). Hasil percobaan ditunjukan oleh kurva garis titik-titik sedangkan hasil simulasi ditunjukan oleh kurva garis kontinu.

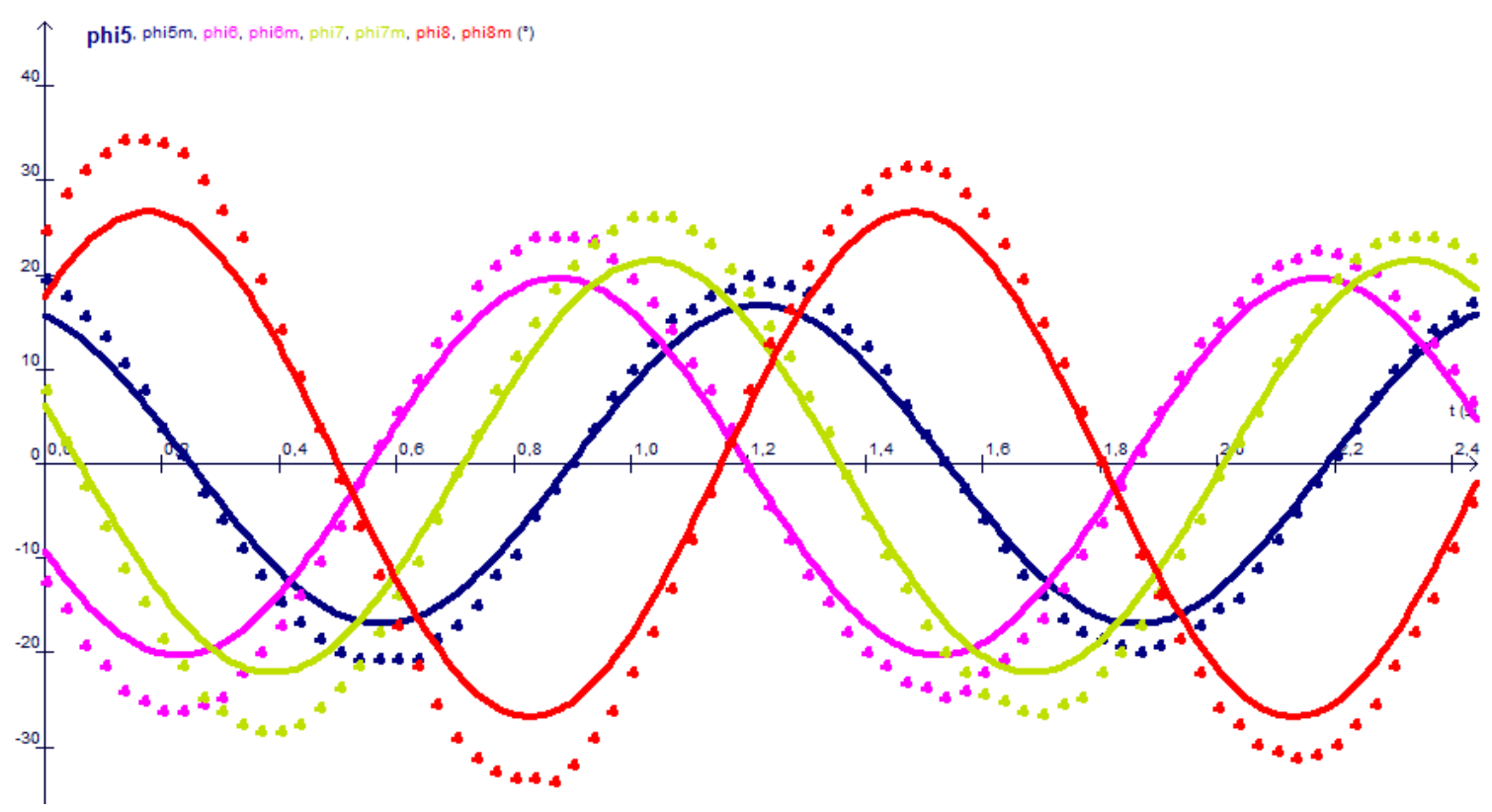

GAMBAR 6. Kurva gerak osilasi harmonis sederhana sistem bandul fisis dengan variasi sudut awalperpindahan besar $20^{\circ}$, $25^{\circ}, 30^{\circ}$ dan $35^{\circ}$. Hasil percobaan ditunukan oleh kurva garis titik-titik sedangkan hasil simulasi ditunjukan oleh kurva garis kontinu.

TABEL 1. Hasil simulasi perhitungan model untuk amplitudo (A) dan perioda (T) osilasi harmonis bandul fisis pada berbagai sudut awal simpangan.

\begin{tabular}{ccc}
\hline $\begin{array}{c}\text { Sudut simpangan } \\
\text { awal (derajat) }\end{array}$ & $\begin{array}{c}\text { A } \\
(\mathbf{c m})\end{array}$ & $\begin{array}{c}\text { T } \\
\text { (detik) }\end{array}$ \\
\hline 5 & 6.67 & 1.29 \\
10 & 8.94 & 1.29 \\
15 & 11.7 & 1.29 \\
20 & 16.8 & 1.29 \\
25 & 20 & 1.30 \\
30 & 21.8 & 1.30 \\
35 & 26.6 & 1.30 \\
\hline
\end{tabular}




\section{Osilasi harmonis sederhana sistem pegas-massa}

Hasil percobaan dari osilasi harmonis sederhana sistem pegas-massa ditunjukan pada GAMBAR 7(a) dan 7(b). Hasil percobaan menunjukan bahwa amplitudo osilasi meningkat seiring dengan peningkatan massa beban sistem.

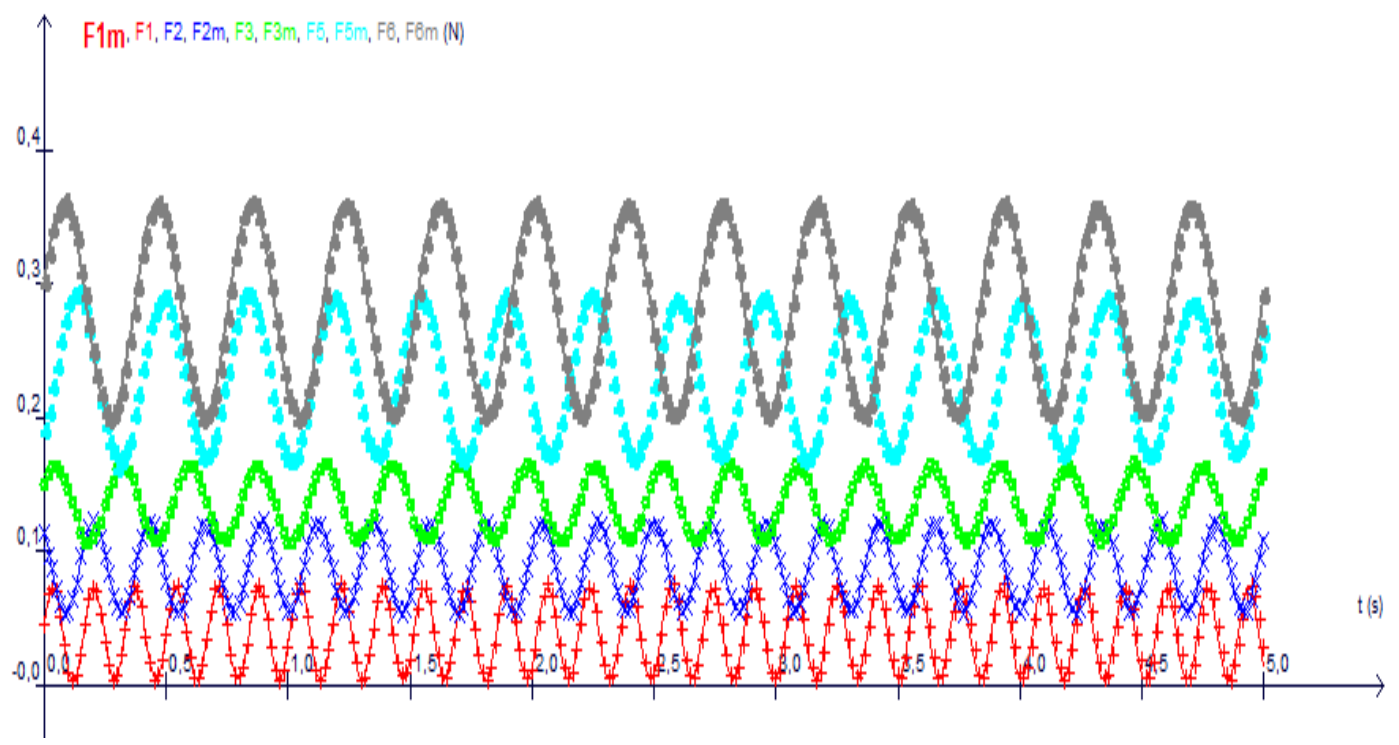

(a)

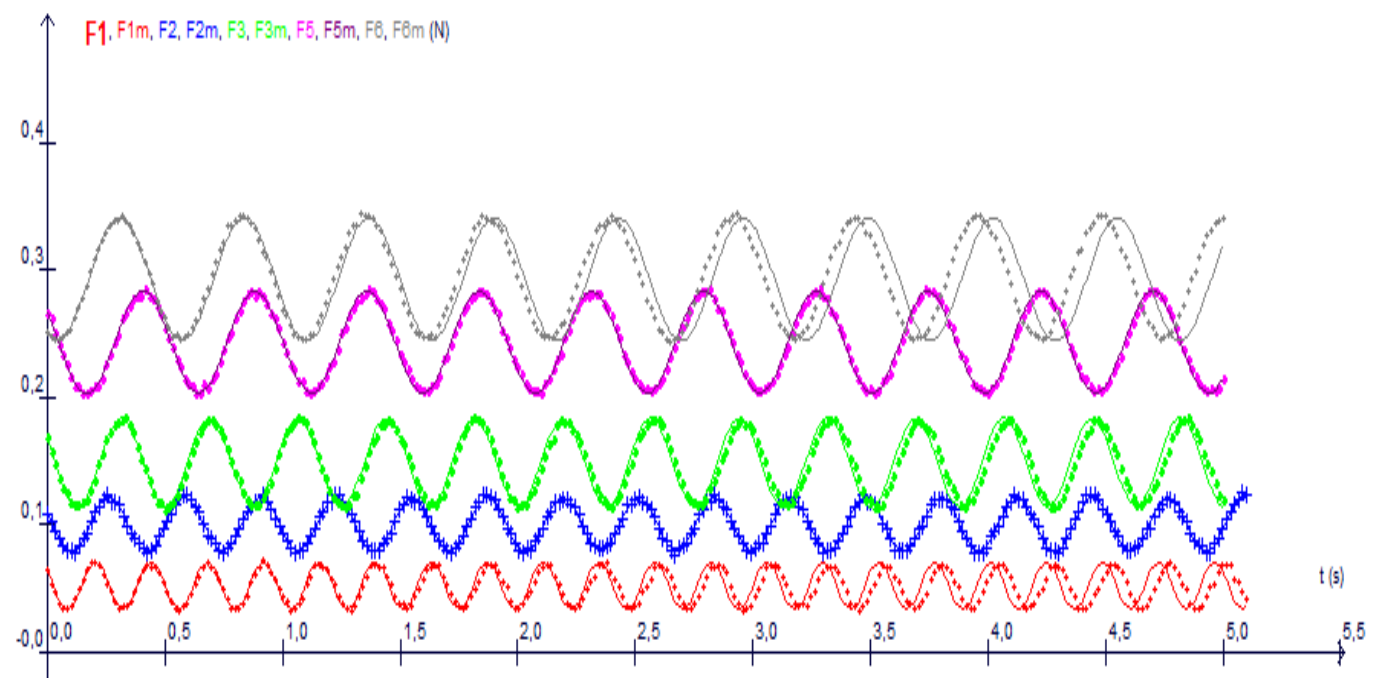

(b)

GAMBAR 7. Osilasi harmonis sederhana pada variasi massa 5, 10, 15, 25 dan 30 gr untuk (a) pegas \#1; (b) pegas \#2.

TABEL 2. Hasil simulasi perhitungan model untuk amplitudo (A) dan perioda (T) serta $T$ hasil percobaan dari osilasi harmonis sederhana sistem pegas-massa pada berbagai massa beban.

\begin{tabular}{ccccc}
\hline Pegas & $\begin{array}{c}\text { Massa } \\
\text { (gram) }\end{array}$ & $\begin{array}{c}\text { A } \\
(\mathbf{c m})\end{array}$ & $\begin{array}{c}\text { T } \\
\text { (detik) }\end{array}$ & $\begin{array}{c}\mathbf{T}_{\text {percob }} \\
\text { (detik) }\end{array}$ \\
\hline$\# 1$ & 5 & 0.0185 & 0.238 & 0,161 \\
& 10 & 0.0212 & 0.322 & 0,228 \\
& 15 & 0.0346 & 0.375 & 0,280 \\
& 25 & 0.0401 & 0.477 & 0,361 \\
$\# 2$ & 30 & 0.0482 & 0.530 & 0,396 \\
& 5 & 0.0185 & 0.238 & 0,211 \\
& 10 & 0.0212 & 0.322 & 0,298 \\
& 15 & 0.0346 & 0.375 & 0,365 \\
& 25 & 0.0401 & 0.477 & 0,472 \\
& 30 & 0.0482 & 0.530 & 0,517 \\
\hline
\end{tabular}


Dari hasil perhitungan secara teori $\left(\omega^{2}=k / m\right)$, menunjukan bahwa amplitudo dan perioda osilasi meningkat seiring dengan peningkatan massa beban sistem.

\section{Pembahasan}

Dapat diasumsikan bahwa kedudukan pusat massa sistem bandul fisis ada di tengah batang bandul, maka persamaan umum gerak osilasinya dapat mengacu pada Persamaan 1. Hasil percobaan menunjukan bahwa gerak osilasi harmonis sederhana, khususnya gerak osilasi sistem bandul fisik, bersesuaian dengan rumusan persamaan umum gerak osilasi sederhana (PERSAMAAN 1) hanya berlaku jika sudut simpangan awal kecil (kurang dari $10^{\circ}$ ) seperti yang dinyatakan oleh rujukan (Serway 2014). Faktor penyebab ketidaksesuaian antara hasil percobaan dengan simulasi antara lain kemungkinan karena semakin besarnya pengaruh gesekan bandul dengan udara sekitar khususnya pada sudut simpangan awal lebih besar dari $10^{\circ}$. Efek gesekan dengan udara sekitar dapat dibuktikan dengan hasil percobaan dimana, secara umum untuk rentang waktu osilasi hingga 10 detik, amplitudo osilasi cenderung berkurang seperti mengalami redaman (GAMBAR 8). Untuk sudut simpangan awal kecil misal $5^{0}$, gerak osilasi dapat dimodelkan dengan kurva sinus (Science Studio software package). Sementara itu untuk perioda osilasi adalah secara umum relatif tetap tidak bergantung pada sudut simpangan awal (TABEL 1). Hal ini membuktikan rumusan teori dimana perioda osilasi hanya bergantung pada panjang batang bandul dan percepatan gravitasi yang keduanya adalah tetap.

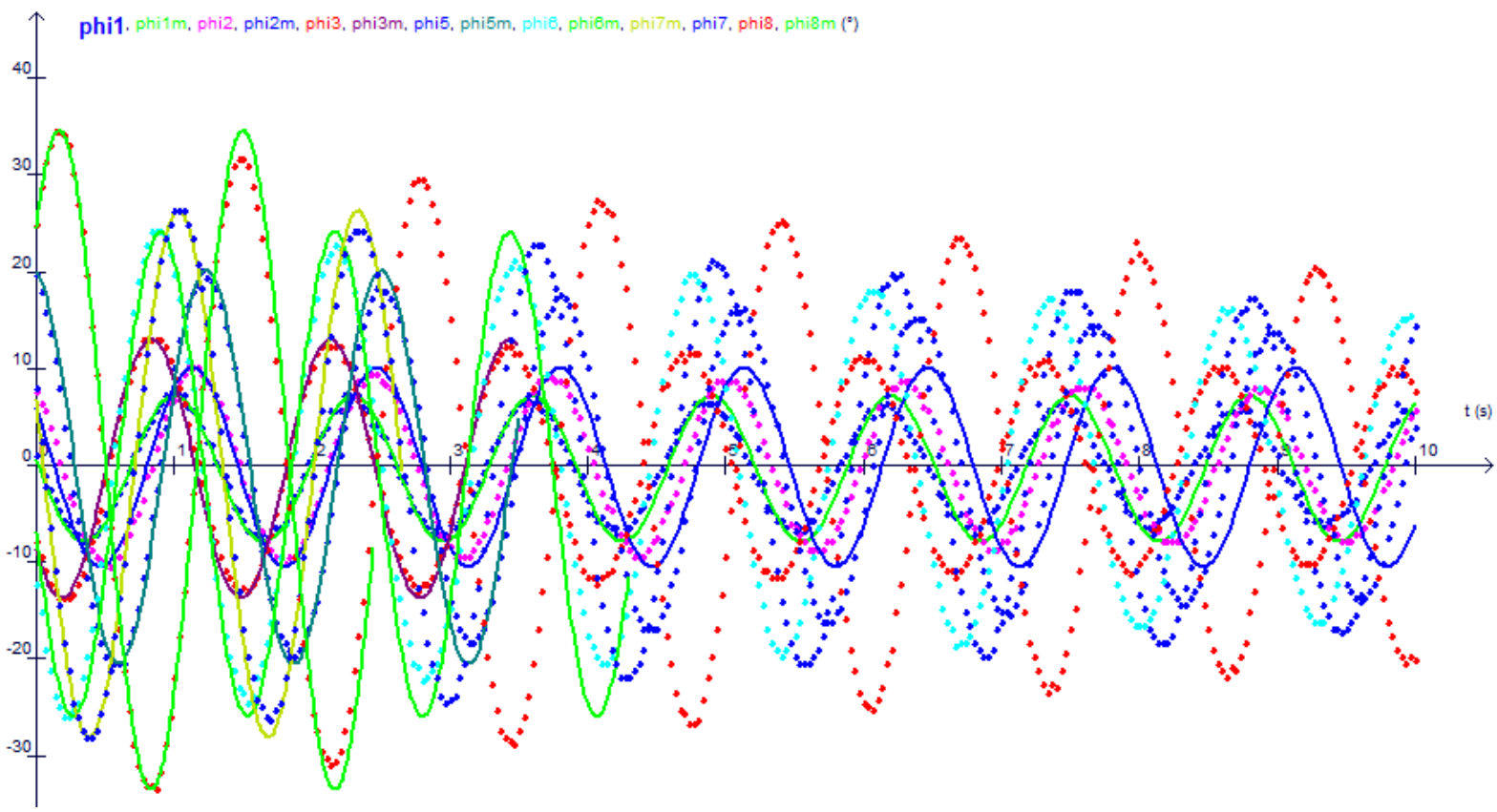

GAMBAR 8. Efek redaman amplitudo osilasi sistem bandul fisis akibat gesekan udara.

Dari hasil percobaan gerak osilasi harmonis sederhana sistem pegas-massa, menunjukan bahwa penambahan massa beban sistem mempengaruhi amplitudo dan perioda osilasi dimana semakin besar massa beban, semakin besar amplitudo dan perioda osilasi. Hasil ini bersesuaian dengan rumusan teori dimana nilai perioda osilasi sebanding dengan akar massa beban sistem (Serway 2014). Perbandingan antara perioda hasil perhitungan teori dengan percobaan (TABEL 2), menunjukan bahwa kesesuaian keduanya ditentukan oleh massa dan tetapan pegas yang digunakan. Pendekatan gerak osilasi harmonis sederhana dari sistem pegas-massa hanya berlaku untuk simpangan awal yang kecil. Penentuan besar atau kecilnya simpangan sistem bergantung pada nilai tetapan pegas yang digunakan serta massa beban yang diberikan. 


\section{SIMPULAN}

Telah dikaji sifat dari gerak osilasi harmonis menggunakan sistem bandul fisis dan sistem pegas massa. Secara umum, gerak sistem bandul fisis, merupakan osilasi harmonis sederhana hanya jika sudut simpangan awal sistem adalah kecil $\left(<10^{\circ}\right)$. Untuk sistem pegas-massa, penentuan simpangan kecil bergantung pada nilai tetapan pegas dan massa beban yang diberikan.

\section{UCAPAN TERIMA KASIH}

Ucapan terima kasih penulis disampaikan kepada Program Studi Fisika dan Pendidikan Fisika FMIPA Universitas Negeri Jakarta untuk fasilitas laboratorium selama percobaan.

\section{DAFTAR PUSTAKA}

Budi, Esmar. Instrumentasi dalam Pendidikan Fisika. Jurusan Fisika FMIPA Universitas Negeri Jakarta, 2013.

Budi, Esmar. Osilasi Harmonis Sederhana. Laporan Percobaan. Jurusan Fisika FMIPA Universitas Negeri Jakarta. 2013.

Ferra Prawati. W., Luthfi Chandra, Nenni Gracia, Umi Munawaroh. Lab. Report of Physical and Mathematical Pendulum. Physics 2013. Faculty of Mathematics and Natural Sciences, State University of Jakarta, 2015 (Laporan Percobaan perkuliahan Gelombang semester 102).

Haliday, D., Resnick, R., Walker, J. Fundamentals of Physics, 8th edition, Extended, John Wiley and sons.

Jeulin. Physics Mechanics: Oscillation of an elastic along a vertical axis (manual sheet of experiment).

Jeulin. Physics Mechanics: Study of simple pendulum (manual sheet of experiment).

Science Studio software package. User manual and scientific tutorial. S.A.V. Jeulin.

Serway, R.A. \& Jewitt, Jr. J.W. Physics for Sccientist and Engineer with Modern Physics, 9th edition, Brooks/Cole : Boston, 2014. 